\title{
Kritisk självreflektion i komplexa frågor: Att hjälpa studenterna att ta makten över sitt tänkande
}

\author{
Maria Wolrath Söderberg* \\ Utvecklingsenheten för högskolepedagogik och bildning, Södertörns högskola
}

\begin{abstract}
Den här artikeln handlar om studenters kritiska självreflektion. Utgångspunkten är att de former av kritiskt tänkande som vi traditionellt odlar inom högskolan är otillräckliga när det gäller vår tids kritiska frågor, som exempelvis klimatfrågan. När det rör sig om komplexa och värdeladdade frågor där många perspektiv kan vara giltiga har vi att förhålla oss till olika mänskliga mekanismer som på olika vis hindrar oss från att tänka och agera klokt, exempelvis polarisering, bekräftelsebias, glapp mellan tanke och handling och olika former av legitimeringsstrategier för att låta blir att ta ansvar. Här diskuteras sådana hinder och hur vi kan förhålla oss till dem i högre utbildning.
\end{abstract}

Nyckelord: Självreflektion, kritiskt tänkande, värdefrågor, klimatfrågor, topos

Självständigt och kritiskt tänkande är ideal som betonas inom akademin. Det finns delade meningar om vad det betyder och hur det ska befordras (för översikter se Bohlin, Ullholm \& Wolrath-Söderberg, 2007; Brodin, 2007; Wolrath Söderberg, 2012). Ett skäl till att det är så viktigt är förstås att det är nödvändiga förmågor i vetenskapligt arbete, men vi föreställer oss nog att det är lika viktigt i arbetslivet och medborgarskapet. Ett annat relevant begrepp som ofta lyfts fram apropå medborgarskapet är medborgerlig bildning (Burman, 20II; Strandbrink et al., 20II). Henrik Bohlin definierar det som "ett systematiskt arbete för att utveckla förmågan att tänka kritiskt och självständigt även i värdefrågor och inte som annars enbart i vetenskapliga frågor inte ett förmedlande av en fördefinierad värdegrund, utan en träning i moraliskt övervägande och praktisk klokhet” (Bohlin, 20II). Som pedagogisk utvecklare tänker jag att alla utbildningar på ett eller annat vis syftar till praktisk klokhet eller fronesis som Aristoteles kallade det (Aristoteles, Retoriken). Studenten ska under utbildningen utveckla de förmågor som behövs för att navigera med sin fackkunskap på ett kritiskt, omdömesgillt och ansvarsfullt sätt i en föränderlig verklighet. Det inkluderar även sådant som analytisk förmåga, civilkurage och integritet. Den här artikeln handlar om en speciell och underbetonad dimension i medborgarskapet och den praktiska klokheten, nämligen den kritiska självreflektionen. Jag diskuterar varför den är viktig, hur den kan förstås och vad som hindrar den. Till sist diskuterar jag också hur den kan befordras pedagogiskt inom ramen för ämnesundervisning. För att göra det tydligt tar jag utgångspunkt i en av vår tids viktigaste samhällsutmaningar - klimatet - och börjar med ett exempel som gäller mig själv.

\footnotetext{
* Författarkontakt: Maria Wolrath Söderberg, maria.wolrath-soderberg@sh.se

Artiklar och reflektioner är kollegialt granskade. Övriga bidragstyper granskas av redaktionen. Se www.hogreutbildning.se ISSN 2000-7558

(C)2017 Maria Wolrath Söderberg. This is an Open Access article distributed under the terms of the Creative Commons Attribution-NonCommercial 4.0 International License (https://creativecommons.org/licenses/by-nc/4.0/), allowing third parties to share their work (copy, distribute, transmit) and to adapt it, under the condition that the authors are given credit, that the work is not used for commercial purposes, and that in the event of reuse or distribution, the terms of this license are made clear.

Citation: Maria Wolrath Söderberg (2017) «Kritisk självreflektion i komplexa frägor: Att hjälpa studenterna att ta makten över sitt tänkande», Högre utbildning 7, 77-90. http://dx.doi.org/10.23865/hu.v7.1024
} 


\section{NOT IN MY BACKYARD}

Jag försöker leva klimatsmart, åker kollektivt, äter vegetariskt, flyger så lite som möjligt. Jag vill lämna så lite avtryck som möjligt till kommande generationer. Jag tror att det är nödvändigt med alternativa energikällor. Men min familj har en liten gård i Bergslagen. Nu planerar man att bygga en av Sveriges största vindkraftsparker i byn, med över trettio I80 meter höga vindsnurror, i skogen där jag plockar blåbär och svamp. Det här gör ont i mig.

Byn är i uppror. Det har skett en polarisering där ungefär hälften av byborna är för vindkraftsparken och ungefär hälften är emot. De förra, varav flera markägare som kommer att få inkomster av vindkraften, lyfter fram nödvändigheten av alternativa energikällor med tanke på klimatet. Och de som är emot pekar på kulturvärden, fågelskydd och har letat fram studier som säger att vindkraft egentligen inte är så effektivt. Omedelbart ville jag ansluta mig till den senare gruppen och drogs kvickt med i ett nyväckt engagemang för en sällsynt grodart som skulle hotas av vindkraftverken. Men så vaknade jag till och upptäckte en sak: jag höll på med NIMBY - not in my backyard-argument. Det är det fulaste som finns för en retoriker (jag är lärare och forskare i retorik). Kvickt nyktrade jag till och insåg att jag ju ändå ämnar fortsätta att använda el. Därför måste jag omorganisera mitt tänkande om vindkraftverken. Jag måste se dem som något vackert, kanske som vindmöllorna i Skåne som jag tycker är så charmiga. Jag är fortfarande inte harmonisk med den blivande vindkraftsparken, men jag tror att jag kan leva med de motstridiga känslorna.

Varför berättar jag det här? Jo, för att den här erfarenheten illustrerar någonting viktigt och aktuellt. För det första hur vårt tänkande präglas av våra känslor, intressen och behov, för det andra hur svårt det är att leva som man vet att man borde när man är tvungen att försaka något, och för det tredje att man i någon mån kan ta makten över sitt tänkande om man ser det.

Exemplet illustrerar också ett problem som gäller vår tids kritiska utmaningar, sådana som har att göra med exempelvis klimat eller naturresurser. Nämligen att det är komplexa frågor där olika värden och intressen ställs mot varandra. De är svåra att hantera även när det finns kunskap och tekniska lösningar, eftersom de kräver beteendeförändringar och kompromisser. Här uppstår ofta en sorts förlamande tröghet som gör att viktigt förändringsarbete fördröjs. En av orsakerna är att vi inte fungerar så rationellt som vi tror.

Den här artikeln adresserar tre omständigheter som försvårar kritiskt tänkande och som blir särskilt problematiska när det gäller hållbarhetsfrågor, den första är just att vi har svårt att hantera kunskap som är komplex. Det andra är den mänskliga mekanism som kommit att kallas the backfire effect (Nyhan \& Reifler, 20IO). Det innebär att vi tenderar att göra motstånd mot kunskap som strider mot våra värden och att till och med omfatta våra felaktiga försanthållanden starkare när de blivit motbevisade. Den tredje är ett närbesläktat fenomen, nämligen att även om vi har kunskap eller bekänner oss till vissa ideal så är det inte säkert att vi handlar i enlighet med detta. Det kallas knowledge-behavior gap respektive attitude-behavior gap (Blake, I999; Kollmuss \& Agyeman, 2002).

Min hypotes är att de sätt varpå vi arbetar med kritiskt tänkande i högre utbildning ofta är otillräckliga för att svara mot de här omständigheterna. Ett skäl är att vi sällan arbetar kritiskt med omdömesfrågor och således inte tränar den förmågan. Ett annat skäl är att det kritiska tänkande vi övar huvudsakligen fokuserar på att se problem i andras tankar, inte i våra egna tankar.

I den här artikeln kommer jag att ta avstamp i forskning om de här tre omständigheterna och sedan på slutet diskutera hur de kan hanteras pedagogiskt i högre utbildning. Jag ställer det hela i relation just till hållbarhetsfrågor eftersom effekterna blir så problematiska här, men perspektiven är sannolikt lika relevanta inom andra fält som har att göra med samhällsutveckling och politik. 


\section{TVÄRSÄKERHETERNAS KAMP SKYMMER SIKTEN}

Först emellertid en titt på det övergripande problemet med trögheten i hållbarhetsfrågor. Just nu lyfts som en förklaringsmodell att vetenskapen utmanas av kunskapsförnekare. Det är riktigt att vi ser sådana trender - faktaresistens breder ut sig och vedertagen kunskap om till exempel klimatet ifrågasätts. Då blir det rimligt att efterfråga mer faktakontroll och respekt för sanning och vetenskap. En biverkan tycks emellertid vara en ökad polarisering mellan olika tvärsäkerheter. På den ena sidan de som instängda i sin facebookbubblor underkänner källor som vi tidigare tagit på allvar. Och på den andra sidan de som i debatten hävdar Sanningen med stort S som den enda kunskapen värd namnet och som likställer perspektivtänkande med löst tyckande och associerar det med kunskapsförnekelse.

Den här polariseringen är bekymmersam på flera vis. För det första för att den ställer omdömet i skuggan. För det andra för att polariseringen ger näring åt backfire-effekten och tvärt om, för det tredje för att många av vår tids kritiska frågor inte är sanningsfrågor utan snarare handlingsfrågor. Det är ett allvarligt problem om högskoleutbildning misslyckas med att rusta studenterna för att kunna förhålla sig kritiskt till sådana tendenser i det egna tänkandet.

\section{KOMPLEXA FRÅGOR KRÄVER OMDÖME}

Många av de frågor som är verkligt svåra att hantera när det gäller mänsklighetens framtid är inte sanningsfrågor i traditionell bemärkelse. De är snarare vad vi kan kalla problematiska frågor. Aristoteles skiljde mellan sanningskunskap (episteme) och omdömeskunskap eller praktisk klokhet (fronesis) (Aristoteles, Retoriken). Episteme ägnar vi oss åt när det gäller kunskap ”som inte kan vara på annat sätt”, till exempel när vi kan räkna oss fram (med matematik eller logik) som när det gäller vinkelsumman i en triangel. Det gör vi också i ganska hög utsträckning i frågor där vi kan observera eller mäta noga (empiriska frågor) och komma fram till säkra svar, exempelvis om hur ögat är konstruerat. Mycket av den befintliga klimatforskningen ägnas åt epistemiska frågor. Ibland blir då kunskapen otvetydig, som att koldioxidhalten i luften principiellt ökar med ökad förbränning av kolbaserat material. Ibland är det svårare att säga med säkerhet, till exempel vilken effekt tinade tundror får på atmosfären. I sådana frågor är det ändå på ett visst sätt, fast vi kanske inte ännu lyckats klura ut mer precist hur det ska beskrivas eller helt enkelt inte har fătt det absolut bekräftat eftersom det ligger i framtiden. Den här sortens kunskap är vi rätt så bra på inom akademin. Vi är bra på kritiskt tänkande och vi är också ganska bra på att undervisa i kritiskt tänkande i den här typen av frågor (Wolrath Söderberg, 20I2).

Det knepiga är emellertid att många av de frågor som verkligen utmanar oss är av fronetisk karaktär. Det är problem "där det kan vara på annat sätt”, där det finns många relevanta perspektiv, även motstridiga, som att tillväxt och konsumtion är tecken på ett samhälles välstånd samtidigt som det tycks vara hot mot långsiktig hållbarhet. Det är problematiska frågor där olika värden krockar, särskilt i konkreta fall, till exempel som i mitt fall med vindkraftsparken. Där krockar värden som att bevara kulturhistoriska platser, rädda våtmarker och min egen nostalgi med ambitionen att skaffa hållbar energi. Det är frågor där vi måste kompromissa med behov och drömmar - kompromissa med varandra och faktiskt också med oss själva. Det är ofta den typen av frågor som vi som medborgare behöver kunna hantera på kloka vis. Med omdöme.

När vi polariserar alternativa fakta mot sanning med stort $S$ och bekänner oss till det senare riskerar vi att lämna walk over för löst tyckande i omdömes- och handlingsfrågor. Det är olyckligt för om vi vill att våra studenter ska kunna verka med sin ämneskompetens på ett kritiskt, omdömesgillt och ansvarsfullt sätt i relation till problematiska frågor så behöver vi ha 
en pedagogik som stödjer fronetiskt kritiskt tänkande och självreflektion. Det är emellertid en svår utmaning (Bohlin et al., 2007; Wolrath Söderberg, 2012).

\section{VÅR RATIONALITET ÄR TJURSKALLIG}

Polariseringen matar emellertid också backfire-effekten. Vi forskare är ofta väl medvetna om vår egen benägenhet till subjektiv tolkning och arbetar därför samvetsgrant med vetenskaplig metod för att minimera risken. Det förhållningssättet försöker vi också att lära våra studenter. Men frågan är om vi rår på backfire-effekten. Vi människor föreställer oss nog gärna att när vi ställs inför fakta som talar i en annan riktning än det vi tidigare hållit för sant så är vi beredda att ändra oss. När det emellertid är viktiga värden eller synsätt som är djupt förankrade i våra vanor, vår bekvämlighet, identitet eller ideologi är det svårt att ändra sig. I själva verket tenderar människor som ställs inför överbevisande skäl att bli ännu starkare i sina gamla uppfattningar (Lord, Ross \& Lepper, 1979; Nyhan \& Reifler, 20I0). Studier visar också att de mest oinformerade ofta är mer tvärsäkra och har mer tillit till sina egna försanthållanden än de mer välinformerade i den aktuella frågan (Bullock, 2007; Kuklinski, Quirk, Jerit, Schwieder \& Rich, 2000). Det hjälper inte heller att försökspersonerna får tillgång till forskning. Försökspersoner tar i större grad till sig forskning som svarar mot deras synsätt och avvisar annan forskning. Särskilt oroväckande är emellertid att det ofta sker med argumentet att vetenskap inte går att lita på (Hart \& Nisbet, 20I2; Munro \& Ditto, 1997). Det är oroväckande att tänka att de argument som vi ofta betraktar som starkast, nämligen de logiska, vetenskapliga, faktabaserade, kanske också väcker det starkaste motståndet (Munro, 20IO). Nya studier visar dessutom att personer som har hög utbildning, hög intelligens eller dokumenterad förmåga till vetenskapligt tänkande inte är skyddade från de här tendenserna. I själva verket påverkas de lika mycket och i några fall mer i sina tolkningar av sina politiska övertygelser. Det verkar som om det traditionellt vetenskapliga kritiska tänkandet och rationaliteten drivs av samma kognitiva processer som också leder till polarisering (Kahan m.fl., 20I2).

Man kan fråga sig varför vi under vissa omständigheter fungerar på det här viset. Neuropsykologer utsatte försökspersoner för information som motsade deras värden och försanthållanden och scannade dem samtidigt med MR-kamera. Undersökningen visade att försökspersonerna som gjorde starkt motstånd när deras försanthållanden utmanades reagerade på liknande sätt som om de hade utsatts för ett fysiskt hot. Särskilt främre insulära cortex aktiverades. Den producerar känslor, så som upplevelser av hot, oro och ångest. Likaså aktiverades amygdalan, som arbetar med tillit respektive skepticism (Kaplan, Gimbel \& Harris, 20I6). De här mekanismerna skapar motstånd mot idéer som hotar vår identitetsuppfattning eller vår kollektiva tillhörighet, ett motstånd som i sin tur återbekräftar och stärker de värderingar man försöker skydda. Det är förstås inte enbart dåligt. Det innebär ju i grunden ett försvar för integriteten och gör oss mindre sårbara, men förhindrar dessvärre också nyttig påverkan.

En annan men inte oförenlig förklaring till att våra försanthållanden är så angelägna för oss att vi är beredda att åsidosätta rationaliteten är att de utgör kitt i våra sociala nätverk. Vi identifierar oss med varandra genom att identifiera oss med gemensamma idéer. Vi förställer oss ju gärna att vi är rationella, men det kan i många sammanhang vara mer rationellt att vara irrationell. Det låter som en paradox om man inte skärskådar idén om rationalitet. Kognitionsoch evolutionsforskarna Mercier och Sperber menar att människans rationalitet inte svarar riktigt mot våra idéer om rationalitet som logiskt, objektivt, autonomt och kontextlöst tänkande. I själva verket har vi kanske överlevt och kommit så långt som vi har eftersom vi har utvecklat 
framgångsrika förmågor att överlägga och komma överens genom argumentation, en tanke som vi förövrigt känner igen hos Aristoteles. Människan kan ha vunnit mer på att vara dialogisk än logisk. Det har inneburit möjligheter till samarbete, samhällsbygge, idéspridning och kulturutveckling som förmodligen varit centrala för vår utveckling, men har också som vi ser sina baksidor (Mercier \& Sperber, 20I7). En spekulation är att baksidorna kanske inte har varit så problematiska historiskt som de är just nu. Backfire-effekten till exempel har kanske fătt idealiskt livsrum i sociala medier.

Vad innebär då kritiskt tänkande som förhåller sig till backfire-effekten? Svaret är att det måste komma inifrån, annars oskadliggörs det lätt av backfire. Det är en utmaning för högre utbildning att stödja utvecklingen av en kritisk självreflektion som så att säga kan upptäcka och ta sin egen backfire-mekanism i örat.

\section{KAN LEVA I KONFLIKT MED HUR VI LÄR}

Man skulle kunna tro att den huvudsakliga förklaringen till varför klimatomställningen går så trögt är att folk inte vet bättre. Visserligen har klimatvetenskapen utmanats den senaste tiden, men i Sverige är motstånd mot klimatforskning eller klimathänsyn ett marginellt fenomen även om det fått mycket plats i medierna. I själva verket har vi en mycket hög andel av befolkningen som är välupplyst i klimatfrågor som dessutom bekänner sig till hållbara ideal (Carlsson, Hammarberg \& Hultin, 20I5). På sätt och vis slåss sanningsivrarna med stort $S$ mot väderkvarnar (i alla fall än så länge). Vårt stora problem tycks istället vara att vi agerar otillräckligt utifrån vår kunskap på såväl politisk som medborgerlig nivå. De här fenomenen som kallas knowledge-behavior gap eller attitude-behavior gap är förstås inte specifikt svenska. I en kanadensisk studie rapporterade $72 \%$ av informanterna att de upplevde att de inte levde så som de visste att de borde (Kennedy, Beckley, McFarlane \& Nadeau, 2009). De senaste decennierna har det gjorts hundratals studier av detta fenomen främst relaterat till hälsa och hållbarhet (Gigliotti, 1992; Kollmuss \& Agyeman, 2002; Vermeir \& Verbeke, 2006).

Hur ska vi då förstå klyftan mellan kunskap och handling? Den kunskapen är väsentlig om vi vill stödja utvecklingen av ett kritiskt förhållningssätt till sådana benägenheter hos studenterna.

\section{Komplexiteten passiviserar}

En förklaring är just att det ofta rör sig om komplexa val och värdekonflikter. Inför sådana är det lätt att kapitulera och bli passiv. Hur man än väljer kan man ju inte göra rätt (Markowitz \& Shariff, 20I2). Att valen är svåra kan också ha att göra med vilken sorts kunskap vi har. Vi kanske är väl medvetna om klimathotets allvar och känner engagemang, men kan inte bedöma hur vi ska agera i konkreta valsituationer: "Är det bäst att köpa ekologiska spanska tomater eller växthusodlade svenska?" Klimathänsyn kan också stå emot andra värden - exempelvis kan det finnas starka skäl för höjd bensinskatt, men det kan stå emot andra hänsyn som rättvisa mellan stad och land. Det här är typexempel på problematiska frågor i Aristoteles bemärkelse. Här hjälper det att ha tillgång till mycket epistemisk kunskap om sakernas tillstånd, och till tekniska lösningar förstås, men man står sig slätt om man inte också kan överlägga och överväga på ett omdömesgillt och kritiskt sätt. Då finns det risk att man blir passiv. Det kan också leda till att man undervärderar hoten (Kollmuss \& Agyeman, 2002).

\section{Vi håller oss på distans}

En annan förklaring har att göra med att klimatproblem upplevs som någon annanstans i rum eller tid. Kollmuss och Agyeman kallar det non-immediacy. Miljöhot är sällan särskilt påtagliga 
eller kännbara (för dem som skulle kunna göra något åt dem). Vi kan till exempel inte föreställa oss växthuseffekt. Inte heller konkreta problem som utdöende arter är något vi personligen upplever även om det har visat sig att det är lättare att väcka engagemang för elefanter än för exempelvis ozonhålet. Här finns också en tidsdimension. Miljöförstöring sker gradvis, men vi har lättare att uppfatta drastiska hot än långsamma. När vi med våra sinnen börjar uppleva miljöproblemen har de ofta hunnit bli riktigt allvarliga (Kollmuss \& Agyeman, 2002). Vi vet sedan länge att människor har svårt att ta till sig sådant de inte har erfarenhet av. En studie efter Deepwater Horizon-katastrofen visar att personer som varit direkt berörda av en miljökatastrof utvecklar ett ökat engagemang för miljön, men att det beror på hur de har berörts. Starkast effekt har det om de har påverkats känslomässigt (Bergstrand \& Mayer, 2017). Då kan det också leda till ändrade vanor (Maiteny, 2002). Känslan verkar sålunda vara en viktig drivkraft när kunskap ska realiseras som handling, men om man nu får en känslomässig reaktion så är det inte säkert att man agerar för det. Det beror också på om man upplever att man har kontroll över situationen och tror att man faktiskt kan göra något åt saken (Kollmuss \& Agyeman, 2002). Det har visat sig att medborgarrörelser och så kallade DIPS, deliberative and inclusionary processes and procedures, är långt mer effektiva när det gäller att få till beteendeförändring än vad informationsöverföring är (Agyeman \& Angus, 2003). Det kan bero på upplevelsen att man kan påverka mer tillsammans än ensam och på att känslor av engagemang tenderar att smitta, men pekar också mot ytterligare en mekanism som visat sig ha betydelse för klimatengagemang och det är den kulturella kontexten och det sociala trycket (Norgaard, 20II). Det här visar att medborgerligt engagemang för klimatet inte kan behandlas som en ren kunskapsfråga eller ur ett rent rationellt perspektiv. De ideal för kritiskt tänkande som vi odlar inom akademin har ofta varit det distanserade och rationella tänkande som brukar sammanfattas i CUDOS-normen (communalism, universalism, disinterestedness och organized skepticism) (Merton, 1973). Det verkar emellertid som om det inte hjälper oss med just de här problemen, utan att vi behöver andra former av kritiskt tänkande som kan hantera erfarenheter, vanor och känslor och som framför allt kan rå på oss själva och vår benägenhet att undandra oss kritiska utmaningar.

\section{Vi legitimerar icke-handling}

En annan förklaring till glappet mellan kunskap och handling har att göra med vår förmåga att legitimera icke-handling. Visserligen vill vi förstås leva som vi lär. Det är skamfullt att inte göra det. Vi är beredda till stora ansträngningar för att rationalisera våra beteenden så att vi kan försvara dem som harmoniska med våra försanthållanden och med vad som betraktas som moraliskt $\mathrm{i}$ vår kultur. Om vi lyckas med det så kan vi köra på. När vi misslyckas hamnar vi $\mathrm{i}$ konflikt med oss själva, ett tillstånd som brukar kallas kognitiv dissonans (Festinger, 1962). Det var vad som hände mig när det gäller vindkraftsparken. Jag försökte legitimera mitt motstånd på en mängd olika sätt, men fick plötsligt syn på vad jag höll på med. Det var mycket frustrerande, för en sådan upplevelse av kognitiv dissonans propsar på ansvarstagande (Dickerson, Thibodeau, Aronson \& Miller, 1992).

Vi tror kanske att mänsklig rationalitet fungerar så att vi har kunskap, principer och intentioner och sedan tillämpar vi dem på nya problem. Mycket tyder emellertid på att vi, när det gäller många typer av mer komplexa problem, fungerar i motsatt riktning. Vi möter ett problem; samtidigt vill vi eller har behov av att göra på ett visst sätt; sedan letar vi reda på argument som binder samman det vi vill med vår kunskap, våra principer och intentioner. Det kallas enthymem inom retorisk teori (Wolrath Söderberg, 20IO) och studerades redan av Aristoteles 
(Retoriken). Det kan verka irrationellt, men ofta fungerar det både snabbt och träffsäkert för att skapa mening av de erfarenheter vi gör. Ibland leder de här legitimeringsprocesserna emellertid till problematiska konsekvenser, och att vi undandrar oss ansvar för vår kunskap. Problemet är att det är svårt att se om man inte är tränad och då är det också svårt att förhålla sig kritiskt till det. Här har vi en viktig utmaning inom högskoleutbildning.

För att tydliggöra vad det här kan innebära i praktiken vill jag lyfta fram några exempel som gäller klimatet. Det gäller alltså sätt som vi använder för att legitimera icke-handling eller handlingar som strider mot vårt bättre vetande eller våra intentioner.

"Billiga" klimatinsatser framför "dyra": Studier visar att det finns ett starkt samband mellan miljöengagerade attityder och vad de kallar "low cost"- beteenden, som att återvinna. Det saknas däremot samband mellan stark attityd och benägenheten till "high cost"- handlingar som att avstå bil eller flygresor (Diekmann \& Preisendörfer, 20I6). En hypotes är att de små miljöhänsynen kan distrahera oss från större mer betydelsefulla insatser, exempelvis att vi låter bli att utmana de större mer problematiska strukturerna. Ett exempel på "billig" handling är klickaktivism, till exempel att man gillar på nätet. En annan är relativt "billig" handling är källsortering. Det gör det möjligt för oss att tänka att vi gjort något bra och då kan vi slå oss till ro.

Klimatkontoidén: En närbesläktad tankestruktur är klimatkontotänkandet. Ett exempel är personen som cyklar till jobbet, källsorterar noggrant och äter mycket bönor, men sedan reser på semester till Thailand och sedan legitimerar det (för sig själv eller andra) med sin cykling, källsortering och sina bönor. Bakom det resonemanget kan vi skymta en idé om att man har ett visst utrymme att belasta klimatet. Det är sällan en särskilt utvecklad idé (tittar man närmare på den ser man att man får källsortera i storleksordningen tjugo år för att spara in de koldioxidutsläpp som en flygresa till Paris ger). Den här idén finns ju också bakom principer som utsläppsrättigheter och kvoter i miljöpolitiken. Det är förstås inget orimligt sätt att tänka, men på det privata planet blir det lätt så att man räknar ansträngningar/uppoffringar snarare än effekter.

Någon annan är ansvarig. Ett vanligt sätt att tänka är att det visserligen är viktigt att något görs men att någon annan är ansvarig. Det kan vara systemet, politikerna, lagarna, marknaden eller andra länder. Det är förstås rimligt att se och försöka påverka strukturella problem. Det intressanta här är att resonemanget också används för att legitimera egen icke-handling. En vanlig sådan idé är tanken att teknologin ska lösa klimatproblemen. Det kan exempelvis vara biologiska flygbränslen eller koldioxidlagring under mark. Studier har visat att de som tror att teknologi och tillväxt ska lösa miljöproblemet är mindre benägna att själva göra uppoffringar (Gigliotti, 1992). Teknologin har emellertid hittills aldrig visat sig hinna ikapp vår ökade användning av resurser. En besläktad tankestruktur är det Alfred Hirschman kallar synergiillusionen som är föreställningen att alla reformer kan kombineras och stärka varandra och inte behöver komma i konflikt (Hirschman, 199I). Det tänkesättet implicerar att vi inte ska behöva uppoffra oss eller kompromissa och syns ofta i argument för icke-handling.

Det finns förstås mängder av andra sätt att legitimera icke-handling. Exempelvis futilitetsargumentet som går ut på att min insats bara kan bli så försumbart liten att den är meningslös. En annan är att göra jämförelser - jag jämför mitt klimatavtryck med andras som är värre. Prioritering av värden som är $i$ harmoni med mitt val innebär att exempelvis att äta kött för att bevara öppna landskap. 


\section{M. W. Söderberg}

Legitimeringsstrategierna hjälper oss att stå ut med oss själva fast vi inte handlar i enlighet med vår kunskap eller våra värden. De fyller tvivelsutan en funktion i många sammanhang genom att skapa mening i vår tillvaro, men de ställer också till problem när de skapar en flyktväg från ansvarstagande. Problemet är att vi ofta är omedvetna om dem. När man väl blir varse vad man håller på med är det svårare att smita. Antagandet i denna artikel är att det är en viktig dimension i kritiskt tänkande att få syn på och reagera på sina egna legitimeringsstrategier så att man kan förhålla sig till dem på ett medvetet sätt.

\section{HUR STÖDJER VI UTVECKLINGEN AV KRITISKT TÄNKANDE FÖR PROBLEMATISKA FRÅGOR?}

Visserligen bekänner vi oss inom akademin gärna till idéer om kritiskt tänkande som både mål och medel för högre utbildning. Men när man tittar närmare på hur detta realiseras i pedagogik kan man se att det kritiska tänkande som avses eller befordras huvudsakligen fokuserar på episteme. Det är min erfarenhet som pedagogisk utvecklare och även i mötet med deltagarna på kursen Att utbilda för kritiskt tänkande och kritikalitet (som vi genomför i samarbete med kollegor på Sveriges lantbruksuniversitet). Gör man en sökning på Studera.nu på "kritiskt tänkande" bekräftas bilden. Huvudsakligen möter vi kritiskt tänkande som logiskt tänkande (att se brister i resonemang), som argumentationsanalytiskt (t.ex. med fokus på felslut), som identiskt med vetenskaplig metod eller som källkritik. (Se även sammanfattningar av akademins praktiker när det gäller kritiskt tänkande i Brodin, 2007; Davies, 20ı5; Wolrath Söderberg, 20I2.) Allt detta är förstås nyttigt, och tvivelsutan viktiga komponenter i praktisk klokhet. Men det är otillräckligt.

Det finns förstås lärare/utbildningar i Sverige som har tagit intryck av perspektiv som kritisk pedagogik eller emancipatoriskt lärande (Freire, 20I4; Kincheloe, 2008; Shor, 1980), transformativt lärande (Cranton, 2006; Mezirow, 199I) och andra idéer som också fokuserar den lärandes egen självreflektion så som Stephen Brookfields tankar om pedagogik för att lära studenter att undersöka och ompröva grundläggande antaganden (20II). Det ligger närmare det som jag här vill diskutera. Kritiskt tänkande har ofta gått ut på att undersöka, problematisera eller finna brister i andras tänkande eller utsagor, medan de här perspektiven och även ibland normkritiken (Kumashiro, 20I2) också undersöker de egna föreställningarna, ofta i relation till det praktiska livet.

Det senare, pedagogik som kopplar det kritiska och vetenskapliga tänkandet till det praktiska livet, finner vi i också pedagogiska idéer som forskningsintegrerad pedagogik (Healey, 2005) och aktiv studentmedverkan (Healey, Flint \& Harrington, 20I4) och dessutom ofta inom casemetodiska ansatser och problembaserat lärande. Här saknas däremot ofta specifik betoning på det självreflekterande kritiska tänkandet. Det finner vi å andra sidan inom formativt lärande som bland annat syftar till att använda återkoppling på sådana vis att den manar den lärande att ta mer och mer eget ansvar för sitt lärande (Black \& Wiliam, I998; Hattie, 2008). Vi finner en än mer specifik betoning på detta med självreflektion inom det som kallas självreglerat lärande (Schraw, Crippen \& Hartley, 2006). Här står medvetenheten och arbetet med det egna lärandet i fokus. Den idébildningen har vuxit fram utifrån begreppet metakognition och brukar härledas till utvecklingspsykologen Johan Flavell. Han syftade på medvetenheten om ens egna kognitiva processer och andra dimensioner av tänkande (Flavell, 1979). Här är perspektivet emellertid ofta individualpsykologiskt och jag tycker att man ofta missar de kollektiva dimensionerna av det egna tänkandet som nödvändigtvis tränger sig på i handlingsfrågor och politiska frågor. 
Forskningen om metakognition har emellertid också kommit att handla om förmågan att på ett medvetet sätt organisera och ta ansvar för sitt eget lärande. Det inkluderar också att organisera undervisning så att den stödjer sådana förmågor (Schraw m.fl., 2006). Det är tankar som är besläktade med det jag är ute efter i denna text. Skillnaden är att det problem jag försöker adressera inte främst är medvetenheten och ansvarstagandet för det egna lärandet, utan medvetenheten och ansvarstagandet för det egna övervägandet i problematiska frägor av den karaktär som klimatfrågan representerar. Sådana frågor är på ett annat sätt än det egna lärandet laddade med värderingar och intressekonflikter och aktualiseras alltid mitt i en väv av behov, intressen, historia och kultur. Här borde man kunna dra nytta av Perkins begrepp troublesome knowledge. Det är kunskap som på olika vis riskerar att undandra sig vår självreflektion. Perkins tar upp fyra former av sådan kunskap: Inert knowledge, det vill säga kunskap eller antaganden som man har men knappt är medveten om, ritual knowledge som man använder rutinmässigt utan att fundera över varför och vad man egentligen menar med den, conceptually difficult knowledge som gäller komplicerade frågor där den intuitiva kunskapen kanske krockar med hur det verkligen är och foreign knowledge, som är svårt att begripa om man inte har tillgång till den kontext där den framväxt (Perkins, 1999). Alla de här formerna av troublesome knowledge behöver man enligt Perkins på olika sätt aktivera, undersöka och problematisera. Perkins teori har huvudsakligen använts för att diskutera hur lärande kan förstås och organiseras i förhållande till ämnesinnehåll, men den har tvivelsutan också relevans för kritisk självreflektion i relation till stora samhällsfrågor. Då behöver vi emellertid kanske lägga till flera former av troublesome knowledge, så som värdeladdad, komplex och föränderlig kunskap. Varken Perkins eller några av de ovan nämnda tänkarna har heller på något mer artikulerat sätt räknat in de hinder för självreflektion som jag tagit upp - så som backfire-effekten och glappet mellan kunskap och handling. Inte heller våra föreställningars beroende av diskursiva strukturer eller legitimeringsstrategier, topos, har fått någon central plats i diskussionen.

Två perspektiv som jag tror kan vara fruktbara för att adressera just det som saknas är den samhällsorienterade och den topiska självreflektiva pedagogiken. Inget av dem är nytt eller originellt i sig, men i relation till de problem jag nyss beskrivit hoppas jag att de kan bidra med perspektiv.

\section{Den sambällsorienterade pedagogiken}

Ett problem som jag ser är att vi ofta arbetar med låtsade problem. Då möter vi inte verklighetens oförutsägbarhet, intressekonflikter och komplexitet, och då får studenterna inte heller öva på att ställas inför situationer där deras värderingar aktiveras och måste hanteras och då deras fronesis utmanas. På senare tid har pedagogiska inriktningar växt fram som försöker svara på detta problem. Ett exempel är det som brukar kallas service learning. Den pedagogiken har växt fram ur den långa traditionen av community service i anglosaxisk undervisningskultur, där många universitet har en verksamhet där medborgare och lokala organisationer kan få hjälp av lärosätets studenter samtidigt som dessa får tillfälle att öva sina kompetenser och detsamma inskolas i ett medborgaransvar. Service learning kallas det när det är integrerat i utbildningen. Den pedagogiska designen bygger på att studenterna ges möjlighet till strukturerad reflektion och teorianknytning med fokus på de aktuella lärandemålen (Jacoby, 1996). I en metastudie som bland annat sammanfattar effekter av service learning lyfts studenternas ökade förståelse av samhällsfenomens komplexitet. Dessutom betonas värdet av erfarenheten av att ha hamnat i dilemman som tvingar fram val, som i sin tur ger material till och behov av reflektion. Lärarna upplever att studenternas förståelse får ett ökat djup och mer nyanser och även ett ökat engagemang och upplevelse 
av mening (Bowen, 20IO). Service learning har också visat sig ha goda effekter på studenternas kritiska tänkande, framför allt när det gäller att se och ompröva egna (och även andras) antaganden, fördomar och försanthållanden, när det gäller förmågan att urskilja alternativ samt när det gäller förmågan att göra omdömesgilla professionella val (Bohlander, 20I4). Det har också visat sig bidra till en fördjupad och mer kritisk och självkritisk förståelse av klimat- och miljöfrågor (Ernst \& Monroe, 2004; Kelly \& Abel, 2012).

En annan inspirationskälla är det som brukar kallas public scholarship (Colbeck \& WhartonMichael, 2006). Ett exempel är ett projekt vid George Mason University i samarbete med National Park Service där studenter och forskare arbetar tillsammans med nationalparkernas personal för att utveckla utbildningar om de riskfaktorer som påverkar parkerna som resultat av klimatförändringar. Ett svenskt exempel är CEMUS, Centrum för Miljö- och utvecklingsstudier i Uppsala. CEMUS, som är helt studentdrivet men finansierat av Uppsala Universitet och Lantbruksuniversitetet, organiserar tvärvetenskapliga utbildningar om hållbarhet och fungerar som en mötesplats för studenter, lärare och forskare och andra aktörer med problem som behöver lösas. Självklart finns det en mängd andra svenska exempel på mer eller mindre utbyggda former av public scholarship exempelvis under beteckningarna utmaningsdriven samverkan eller Open lab.

Inom mitt eget ämne retorik utvecklas just nu något som kallas participatory critical rhetoric (Middleton, Hess, Endres \& Senda-Cook, 2015). Det bygger på att forskare tillsammans med studenter analyserar aktuell, autentisk retorik och att de går i konversation med debattörer och publiker, med sina retoriska kritiska perspektiv. Det kan också inbegripa metadiskussioner om de diskursiva valen och det kan handla om att bidra till att lyfta fram eller ge röst åt marginaliserade perspektiv. Man gör sålunda deltagande i debatt och förändringsarbete till föremål för forskning. På så vis dras studenterna in i ett forskande och kritiskt förhållningssätt till sitt eget ämne i relation till praktiken.

Den närmast sömlösa mixen av forskning, utbildning och konsultativt stöd som vi ser inom de här pedagogiska ansatserna aktualiserar förstås svårigheter av olika slag som har att göra med forskningens integritet och som man får tampas med på olika vis. Men ett större problem ur ett pedagogiskt perspektiv kan vara att det är en utmaning för läraren.

Det som skapar särskilt goda förutsättningar för den sortens lärande som jag här efterfrågar är just komplexiteten, bristen på förutsägbarhet och att praktikens problem kommer laddade med värdedimensioner och konflikter. Det man får på köpet är också studentens (och ofta även lärarens) ökade upplevelse av mening som ju är en betydelsefull parameter i lärande (Matusov, 20II). Det är emellertid också det som kräver mycket av oss lärare. Det är svårt att planera, det är svårt att ha kontroll och det kan innebära risktagande. De flesta lärare är ovana att arbeta så. Det kräver övning och andra planeringsförutsättningar, exempelvis annan logistik, och det blir viktigt med kollegial planering och ett progressionstänkande som gäller studentens inskolning i en viss självständighet. Om lärandet ska leda till det kritiska och självkritiska tänkande jag eftersöker i den här artikeln behövs också pedagogiska verktyg för metareflektion och självreflektion. Detta verkar vara en kritisk faktor för den samhällsintegrerade undervisningens effekter på lärande (Bowen, 20IO). Här vittnar lärare som jag möter i min roll som pedagogisk utvecklare om osäkerhet. Det är här idén om det topiska kommer in.

Den topiska självreflekterande pedagogiken

En utgångspunkt är att det är svårt att se sitt eget tänkande. Vi kan inte titta in i hjärnan på oss själva. Däremot kan vi träna på att höra oss själva (eller se vad vi skriver). Om vi emellertid 
utgår från antagandet att våra tankar struktureras diskursivt, det vill säga att vi organiserar vårt tänkande med hjälp av språket, så är det rimligt att anta att vi kan få syn på vårt tänkande via hur det tar sig uttryck i resonemang och argument. Den tanken känns igen från många håll, från Aristoteles till modern diskursanalys och sociokulturella teorier om lärande.

Problemet är att vi ofta saknar vokabulär och vana att urskilja och artikulera hur vi tänker. En sådan erbjuder emellertid retoriken i toposläran och den kan användas pedagogiskt för att befordra studentens kritiska tänkande i komplexa och värdeladdade samhällsfrågor (Wolrath Söderberg, 20I2, 20I6).

Den retoriska toposläran var ursprungligen en metod för att resonera i problematiska frågor som exempelvis gäller etik, juridik eller politik (Wolrath Söderberg, 2017). På senare år har den dammats av som ett redskap för kritisk reflektion, exempelvis om klimatfrågor (Ross, 20I7; Walsh \& Boyle, 2017). Toposläran bygger på att man ser mänskligt övervägande som en förhandling mellan topos. Topos är strukturer med vars hjälp vi organiserar våra tolkningar och skapar mening ur det vi upplever. Det kan vara frågor som vi återkommer till och prioriterar. Det kan vara återkommande perspektiv, betonade värden och försanthållanden. Det kan vara tankestrukturer som narrativ, metaforer, metonymier, antiteser, analogier, orsakssamband eller syllogismer. Det går inte att resonera toposfritt. På något sätt måste vi skapa mening, men hur vi gör det påverkar vad vi drar för slutsatser och hur det blir rimligt att tänka och agera. Ett exempel är hur jag började legitimera mitt vindkraftsmotstånd med hjälp av hänvisningar till värden som skyddsvärda arter och kulturhistoria och genom att prioritera fakta som talade mot vindkraftens effektivitet. $\mathrm{Nu}$ fick jag syn på min egen toposanvändning, men den är ofta omedveten; topos är svåra att se för att de för oss framstår som normala. De olika legitimeringsstrategierna för icke-handling $\mathrm{i}$ klimatfrågan som jag nyss gick igenom är alla exempel på topos.

Tanken här är att man kan lära sig att urskilja, känna igen, se alternativ, ompröva och byta ut topos och på så vis utveckla en mer problematiserande och självkritisk reflektion. Toposläran erbjuder en vokabulär för att göra tankestrukturer (i bred bemärkelse) synliga och möjliga att artikulera och diskutera. Det är sålunda en metod för kritiskt tänkande, men som skiljer sig från de metoder som sammanfattas med CUDOS-normen. Här vill jag påminna om Kahans forskning som pekar mot att vetenskaplig rationalitet i sig inte skyddar mot backfire-effekter eller polarisering utan möjligen konstitueras av samma typ av sambandsskapande rationalitet (Kahan m.fl., 20I2). Toposläran skiljer sig dels genom inifrånperspektivet och dels genom att möjliggöra alternativa tankesätt som har potential att "rädda" identitetsupplevelsen och en eventuell kulturell identifikation, något som visat sig nödvändigt för att det ska vara möjligt att överbrygga tendenser till ideologiskt färgad tolkning. Kahan sammanfattar det som att om vi måste välja mellan att använda vårt tänkande för att vara den vi är eller att veta det som vetenskapen vet, så väljer vi det föregående (Kahan, Landrum, Carpenter, Helft \& Hall Jamieson, 2017). Toposläran, tänker jag, hjälper oss att vara den vi är och samtidigt tänka kritiskt. Det har en viss relevans även i epistemiska frågor, men blir särskilt relevant i problematiska frågor.

Problemet är att topiskt tänkande måste övas och praktiseras. I en tidigare artikel i denna tidskrift beskriver jag konkreta övningar som går att integrera med ämnesundervisning (Wolrath Söderberg, 20I6). Förutom att grundlägga vanan att undersöka och begreppslägga våra tankestrukturer är ett bra sätt att göra det genom deliberation, diskussion eller debatt. Våra topos framträder nämligen tydligare mot alternativa topos, och deras potential och värde prövas bäst de bryts mot varandra i dialog. Men det är knappast någon idé att jämföra topos på ett generellt plan, utan det är just i relation till konkreta situationer, då backfire-effekten slår till, eller då 
man frestas att legitimera glappet mellan kunskap och handling, som den topiska dialogen blir meningsfull. Den kommer att göra ont, för det är smärtsamt att se sig själv i vitögat, men den blir fruktbar.

\section{FÖRFATTARPRESENTATION}

Maria Wolrath Söderberg är lektor i retorik och ledare för Utvecklingsenheten för högskolepedagogik och bildning vid Södertörns högskola.

\section{REFERENSER}

Agyeman, J., \& Angus, B. (2003). The Role of Civic Environmentalism in the Pursuit of Sustainable Communities. Journal of Environmental Planning and Management, 46(3), 345-363.

Aristoteles. Retoriken.

Bergstrand, K., \& Mayer, B. (2017). Transformative environmental threats: behavioral and attitudinal change five years after the deepwater horizon oil spill. Environmental Sociology, o(o), I-II.

Black, P., \& Wiliam, D. (1998). Assessment and Classroom Learning. Assessment in Education: Principles, Policy \& Practice, 5(I), 7-74.

Blake, J. (1999). Overcoming the 'value-action gap' in environmental policy: Tensions between national policy and local experience. Local Environment, 4(3), 257-278.

Bohlander, K. (20I4). Enhancing Critical Thinking Through Service-Learning as a Consultative Process. Developments in Business Simulation and Experiential Learning, 37, 293-300.

Bohlin, H. (20II). Vad är medborgerlig bildning? I P. Strandbrink, B. Lindqvist, \& H. Forsberg (Red.), Tvära möten: Om utbildning och kritiskt lärande (s. 19-34).

Bohlin, H., Ullholm, A., \& Wolrath-Söderberg, M. (2007). Critical thinking for a pluralistic university. Solsko Polje/The School Field. International Journal of Theory and Research in Education, Vol. I8, No. I/2:, I8(I/2), III-II7.

Bowen, G. (2010). Service Learning in the Scholarship of Teaching and Learning: Effective Practices. International Journal for the Scholarship of Teaching and Learning, 4(2), Article I8.

Brodin, E. (2007). Critical Thinking in Scholarship: Meanings, Conditions and Development. Department of Education, Lund University.

Brookfield, S. (20II). Teaching for Critical Thinking: Tools and Techniques to Help Students Question Their Assumptions. Jossey-Bass

Bullock, J. G. (2007). Experiments on partisanship and public opinion: Party cues, false beliefs, and Bayesian updating. Stanford.

Burman, A. (Red.) (20II). Vaga veta!: Om bildningens möjligheter i massutbildningens tidevarv. Södertörn Studies in Higher Education.

Carlsson, K., Hammarberg, R., \& Hultin, K. (2015). Allmänheten och klimatförändringen 2015. Naturvårdsverket.

Colbeck, C. L., \& Wharton-Michael, P. (2006). Individual and organizational influences on faculty members' engagement in public scholarship. New Directions for Teaching and Learning, 2006(I05), 17-26.

Cranton, P. (2006). Understanding and Promoting Transformative Learning: A Guide for Educators of Adults. Wiley.

Davies, M. (20I5). A Model of Critical Thinking in Higher Education. I M. Davies \& R. Barnett (Red.), The Palgrave Handbook of Critical Thinking in Higher Education, 4I-92. Springer.

Dickerson, C. A., Thibodeau, R., Aronson, E., \& Miller, D. (1992). Using Cognitive Dissonance to Encourage Water Conservation. Journal of Applied Social Psychology, 22(II), 84I-854.

Diekmann, A., \& Preisendörfer, P. (2016). Umweltbewußtsein und Umweltverhalten in Low- und High-Cost-Situationen. Zeitschrift für Soziologie, 27(6), 438-453.

Ernst, J., \& Monroe, M. (2004). The effects of environment-based education on students' critical thinking skills and disposition toward critical thinking. Environmental Education Research, IO(4), 507-522. 
Festinger, L. (1962). A Theory of Cognitive Dissonance. Stanford University Press.

Flavell, J. (1979). Metacognition and Cognitive Monitoring: A New Area of Cognitive-Developmental Inquiry. American Psychologist, 34(I0), 906-9II.

Freire, P. (20I4). Pedagogy of the Oppressed: 3oth Anniversary Edition. Bloomsbury Publishing USA.

Gigliotti, L. M. (1992). Environmental Attitudes: 20 Years of Change? The Journal of Environmental Education, 24(I), I5-26.

Hart, S., \& Nisbet, E. C. (20I2). Boomerang Effects in Science. Communication Research - P., 39(6), $70 \mathrm{I}-723$.

Hattie, J. (2008). Visible Learning: A Synthesis of Over 800 Meta-Analyses Relating to Achievement. Routledge.

Healey, M. (2005). Linking research and teaching exploring disciplinary spaces and the role of inquiry-based learning. I R. Barnett (Red.), Reshaping the university: New relationships between research, scholarship and teaching (s. 67-78). Maidenhead: McGraw-Hill/Open University Press.

Healey, M., Flint, A., \& Harrington, K. (2014). Engagement through Partnership: students as partners in learning and teaching in higher education. York: Higher Education Academy.

Hirschman, A. O. (1991). The Rhetoric of Reaction. Harvard University Press.

Jacoby, B. (1996). Service-learning in higher education: concepts and practices. Jossey-Bass Publishers.

Kahan, D. M., Peters, E., Wittlin, M., Slovic, P., Ouellette, L. L., Braman, D., \& Mandel, G. (2012). The polarizing impact of science literacy and numeracy on perceived climate change risks. Nature Climate Change, 2(10), 732-735.

Kahan, D. M., Landrum, A., Carpenter, K., Helft, L., \& Hall Jamieson, K. (20I7). Science Curiosity and Political Information Processing. Political Psychology, 38, I79-199.

Kaplan, J. T., Gimbel, S. I., \& Harris, S. (20I6). Neural correlates of maintaining one's political beliefs in the face of counterevidence. Scientific Reports, 6, scientific report 39589.

Kelly, J., \& Abel, T. (2012). Fostering Ecological Citizenship: The Case of Environmental Service-Learning in Costa Rica. International Journal for the Scholarship of Teaching and Learning, 6(2), Article I6.

Kennedy, E. H., Beckley, T. M., McFarlane, B. L., \& Nadeau, S. (2009). Why we don't" walk the talk": Understanding the environmental values/behaviour gap in Canada. Human Ecology Review, I5I-160.

Kincheloe, J. L. (2008). Critical Pedagogy Primer. Peter Lang.

Kollmuss, A., \& Agyeman, J. (2002). Mind the Gap: Why do people act environmentally and what are the barriers to pro-environmental behavior? Environmental Education Research, 8(3), 239-260.

Kuklinski, J. H., Quirk, P. J., Jerit, J., Schwieder, D., \& Rich, R. F. (2000). Misinformation and the Currency of Democratic Citizenship. The Journal of Politics, 62(3), 790-816.

Kumashiro, K. (2012). Troubling Education: "Queer" Activism and Anti-Oppressive Pedagogy. Routledge.

Lord, C. G., Ross, L., \& Lepper, M. R. (1979). Biased assimilation and attitude polarization: The effects of prior theories on subsequently considered evidence. Journal of Personality and Social Psychology, 37(II), 2098-2109.

Maiteny, P. T. (2002). Mind in the Gap: Summary of research exploring "inner" influences on pro-sustainability learning and behaviour. Environmental Education Research, 8(3), 299-306.

Markowitz, E. M., \& Shariff, A. F. (20I2). Climate change and moral judgement. Nature Climate Change, $2(4), 243-247$.

Matusov, E. (20II). Irreconcilable differences in Vygotsky's and Bakhtin's approaches to the social and the individual: An educational perspective. Culture \& Psychology, I7(I), 99-II9.

Mercier, H., \& Sperber, D. (2017). The Enigma of Reason. Harvard University Press.

Merton, R. K. (1973). The Sociology of Science: Theoretical and Empirical Investigations. University of Chicago Press.

Mezirow, J. (1991). Transformative Dimensions of Adult Learning. Wiley.

Middleton, M., Hess, A., Endres, D., \& Senda-Cook, S. (2015). Participatory Critical Rhetoric: Theoretical and Methodological Foundations for Studying Rhetoric in Situ. Lexington Books.

Munro, G. D. (20I0). The Scientific Impotence Excuse: Discounting Belief-Threatening Scientific Abstracts. Journal of Applied Social Psychology, 40(3), 579-600. 


\section{M. W. Söderberg}

Munro, G. D., \& Ditto, P. H. (1997). Biased Assimilation, Attitude Polarization, and Affect in Reactions to Stereotype-Relevant Scientific Information. Personality and Social Psychology Bulletin, 23(6), 636-653. Norgaard, K. M. (20II). Living in Denial: Climate Change, Emotions, and Everyday Life. MIT Press.

Nyhan, B., \& Reifler, J. (20Io). When Corrections Fail: The Persistence of Political Misperceptions. Political Behavior, 32(2), 303-330.

Perkins, D. (1999). The Many Faces of Constructivism. Educational Leadership, 57(3), 6-II.

Ross, D. G. (2017). Topic-Driven Environmental Rhetoric. Routledge.

Schraw, G., Crippen, K. J., \& Hartley, K. (2006). Promoting Self-Regulation in Science Education: Metacognition as Part of a Broader Perspective on Learning. Research in Science Education,

Shor, I. (1980). Critical Teaching and Everyday Life. University of Chicago Press.

Strandbrink, P., Lindqvist, B. \& Forsberg, H. (Red) (20II). Tvära möten: Om utbildning och kritiskt lärande. Södertörn studies in Education.

Vermeir, I., \& Verbeke, W. (2006). Sustainable Food Consumption: Exploring the Consumer "Attitude Behavioral Intention" Gap. Journal of Agricultural and Environmental Ethics, 19(2), I69-194.

Walsh, L., \& Boyle, C. (20I7). Topologies as Techniques for a Post-Critical Rhetoric. Springer.

Wolrath Söderberg, M. (2010). Aristoteles enthymem. Rhetorica Scandinavica, (53), 36-66.

Wolrath Söderberg, M. (20I2). Topos som meningsskapare: retorikens topiska perspektiv på tänkande och lärande genom argumentation. Ödåkra: Retorikförlaget.

Wolrath Söderberg, M. (2016). Att få ihop teorier, praktik och kritiskt tänkande i seminariet - ett topiskt förslag. Högre utbildning, 6(I), 3I-49.

Wolrath Söderberg, M. (20I7). Aristoteles retoriska toposlära - en verktygsrepertoar för fronesis. Huddinge: Södertörn Rhetorical Studies. 